\title{
BIOLOGICAL INTEGRITY OF STREAMS IN THE MADISON RIVER TMDL PLANNING AREA BASED ON THE STRUCTURE AND COMPOSITION OF THE BENTHIC ALGAE COMMUNITY
}

\author{
Prepared for: \\ State of Montana \\ Department of Environmental Quality \\ P.O. Box 200901 \\ Helena, Montana 59620-0901 \\ Project Officer: Al Nixon \\ DEQ Contract No. 200012-10
}

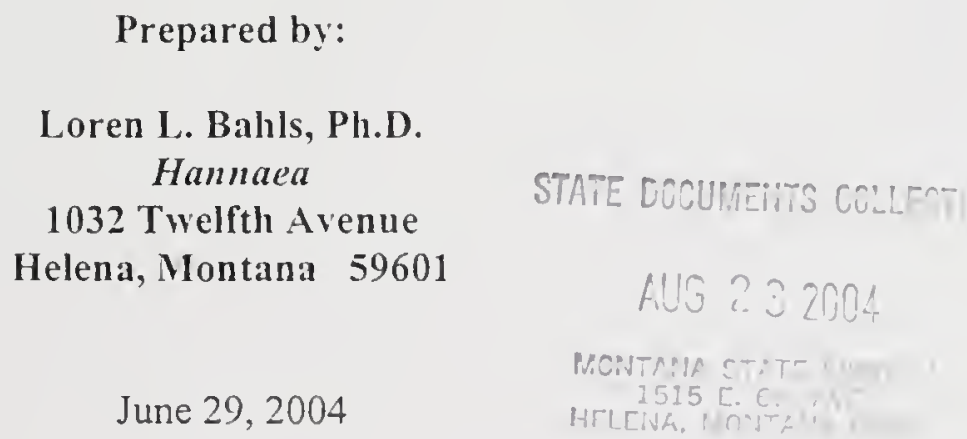


- 


\section{Summary}

In the summer of 2003, periphyton samples were collected from 10 sites on 5 streams in the Madison River TMDL planning area in southwestern Montana for the purpose of assessing whether these streams are water-quality limited and in need of TMDLs. The samples were collected following MDEQ standard operating procedures, processed and analyzed following standard methods for periphyton, and evaluated following modified USEPA rapid bioassessment protocols for wadeable streams.

Diatom metrics indicate moderate impairment (from sedimentation) and less than full support of aquatic life uses at only one site: Elk River at end of West Fork Madison River Road. Although this site had an elevated sedimentation index, it was virtually identical, floristically, with the upstream site on Elk River.

All of the other sites registered only minor impairment and provided full support of aquatic life uses. The prevailing cause of impairment at these sites was sedimentation, which resulted in minor impairnent at all sites except the upper site on Gazelle Creek and the upper site on Blaine Spring Creek. Minor impairment from organic loading was noted in Antelope Creek and in Blaine Spring Creek below the fish hatchery.

All but one of the sites (Blaine Spring Creek near mouth) supported at least a few abnormal diatom cells. Most sites are within the normal range for abnormal cell numbers. Gazelle Creek supported the largest percentage of abnormal cells (1.08-1.44\%) and these may indicate chronic toxicity from heavy metals.

Blaine Spring Creek at bypass supported a distinctive diatom flora that indicates lower $\mathrm{pH}$ and lower water temperatures compared to the other sites in the sample set. Naturally austere conditions here resulted in depressed diatom species richness and diversity values. This site had little in common, floristically, with the next site downstream (below fish hatchery). 


\section{Introduction}

This report evaluates the biological integrity ${ }^{1}$, support of aquatic life uses, and probable causes of stress or impairment to aquatic communities at 10 sites on 5 streams in the Madison River TMDL Planning Area of southwestern Montana. The purpose of this report is to provide information that will help the State of Montana determine whether these streams are waterquality limited and in need of TMDLs.

The federal Clean Water Act directs states to develop water pollution control plans (Total Maximum Daily Loads or TMDLs) that set limits on pollution loading to water-quality limited waters. Water-quality limited waters are lakes and stream segments that do not meet waterquality standards, that is, that do not fully support their beneficial uses. The Clean Water Act and USEPA regulations require each state to (1) identify waters that are water-quality limited, (2) prioritize and target waters for TMDLs, and (3) develop TMDL plans to attain and maintain water-quality standards for all water-quality limited waters.

Evaluation of aquatic life use support in this report is based on the species composition and structure of periphyton (aka benthic algae, phytobenthos) communities that were sampled in the summer of 2003. Periphyton is a diverse assortment of simple photosynthetic organisms called algae that live attached to or in close proximity of the stream bottom. Some algae form long filaments or large gelatinous colonies that are conspicuous to the unaided eye. But most algae, including the ubiquitous diatoms, can be seen and identified only with the aid of a microscope. The periphyton community is a basic biological component of all aquatic ecosystems. Periphyton accounts for much of the primary production and biological diversity in Montana streams (Bahls et al. 1992). Plafkin et al. (1989) and Barbour et al. (1999) list several advantages of using periphyton in biological assessments.

\footnotetext{
'Biological integrity is defined as "the ability of an aquatic ecosystem to support and maintain a balanced, integrated, adaptive community of organisms having a species composition, diversity, and functional organization comparable to that of natural habitats within a region" (Kart and Dudley 1981).
} 


\section{Project Area and Sampling Sites}

The project area is located within the Middle Rockies Ecoregion (USEPA 2000). The Madison River heads in Yellowstone National Park and its watershed occupies a high mountain basin in southwestern Montana. The surface geology of the watershed is complex, consisting mostly of high-grade metamorphic rocks and rhyolitic volcanic rocks in the uplands and Tertiary basin fill in the Madison River Valley (Renfro and Feray 1972). Climax vegetation consists of alpine tundra at the highest elevations, Douglas-fir and subalpine fir forest at intermediate elevations, and mixed grassland/sagebrush steppe at lower elevations. The main land uses are recreation, logging, ranching, and mining.

Periphyton samples were collected at 10 sites on 5 tributaries of the Madison River (Table 1). All sites are in USGS HUC 10020007 and are classified B-1 in the Montana Surface Water Quality Standards.

\section{Methods}

Periphyton samples were collected following standard operating procedures of the MDEQ Planning, Prevention, and Assistance Division. Using appropriate tools, microalgae were scraped, brushed, or sucked from natural substrates in proportion to the importance of those substrates at each study site. Macroalgae were picked by hand in proportion to their abundance at the site. All collections of microalgae and macroalgae were pooled into a common container and preserved with Lugol's (IKI) solution.

The samples were examined to estimate the relative abundance of cells and rank by biovolume of diatoms and genera of soft (non-diatom) algae according to the method described in Bahls (1993). Soft algae were identified using Smith (1950), Prescott $(1962,1978)$, John et al. (2002), and Wehr and Sheath (2003). These books also served as references on the ecology of the soft algae, along with Palmer $(1969,1977)$. 
After the identification of soft algae, the raw periphyton samples were cleaned of organic matter using sulfuric acid, potassium dichromate, and hydrogen peroxide. Then permanent diatom slides were prepared using Naphrax ${ }^{\mathrm{TM}}$, a high refractive index mounting medium, following Standard Methods for the Examination of Water and Wastewater (APHA 1998). At least 400 diatom cells ( 800 valves) were counted at random and identified to species. The following were the main taxonomic references for the diatoms: Krammer and Lange-Bertalot 1986, 1988, 1991 a, 1991b; Lange-Bertalot 1993, 2001; Krammer 1997a, 1997b, 2002; Reichardt 1997, 1999. Diatom naming conventions followed those adopted by the Academy of Natural Sciences for USGS NAWQA samples (Morales and Potapova 2000). Van Dam et al. (1994) was the main ecological reference for the diatoms.

The diatom proportional counts were used to generate an array of diatom association metrics. A metric is a characteristic of the biota that changes in some predictable way with increased human influence (Barbour et al. 1999). Diatoms are particularly useful in generating metrics because there is a wealth of information available in the literature regarding the pollution tolerances and water quality preferences of common diatom species (e.g., Lowe 1974, Beaver 1981, Lange-Bertalot 1996, Van Dam et al. 1994).

Values for selected metrics were compared to biocriteria (numeric thresholds) developed for streams in the Rocky Mountain ecoregions of Montana (Table 2). These criteria are based on metric values measured in least-impaired reference streams (Bahls et al. 1992) and metric values measured in streams that are known to be impaired by various sources and causes of pollution (Bahls 1993). The criteria in Table 2 are valid only for samples collected during the summer field season (June 21 -September 21 ) and distinguish among four levels of stress or impairment and three levels of aquatic life use support: (1) no impairment or only minor impairment (full support); (2) moderate impairment (partial support); and (3) severe impairment (nonsupport). These impairment levels correspond to excellent, good, fair, and poor biological integrity, respectively. In cold, high-gradient mountain streams, natural stressors will often mimic the effects of man-caused impairment on some metric values. 


\section{Quality Assurance}

Several steps were taken to assure that the study results are accurate and reproducible. Upon receipt of the samples, station and sample attribute data were recorded in the Montana Diatom Database and the samples were assigned a unique number, e.g., 3054-01. The first part of this number (3054) designates the sampling site (Antelope Creek at Antelope Basin Road) and the second part ( 01$)$ designates the number of periphyton samples that that have been collected at this site for which data have been entered into the Montana Diatom Database.

Sample observations and analyses of soft (non-diatom) algae were recorded in a lab notebook along with information on the sample label. A portion of the raw sample was used to make duplicate diatom slides. The slides used for the diatom proportional counts will be deposited in the Montana Diatom Collection at the University of Montana Herbarium (MONTU) in Missoula. Duplicate slides will be retained by Hannaea in Helena. Diatom proportional counts have been entered into the Montana Diatom Database.

\section{Results and Discussion}

Results are presented in Tables 3, 4, 5, and 6 which are located near the end of this report following the references section. Appendix A contains a diatom report for each sample. Each diatom report includes an alphabetical list of diatom species in that sample and their percent abundances, and values for 65 different diatom metrics and ecological attributes.

\section{Sample Notes (Table 3)}

Notes on the contents and condition of each sample are recorded in Table 3. Several samples contained varying amounts of sediment and plant material other than algae. 


\section{Non-Diatom Algae (Table 4)}

Twenty-two genera representing five divisions of non-diatom algae were found in samples that were collected from tributaries of the Madison River in 2003 (Table 4). Divisions represented by the most genera were Chlorophyta or green algae (12 genera) and Cyanophyta or cyanobacteria ( 6 genera). The Division Chrysophyta (yellow-green algae) was represented by two genera and the Divisions Rhodophyta (red algae) and Phaeophyta (brown algae) were represented by one genus each.

Cyanobacteria were found in all 10 samples and green algae were found in all but one sample (Blaine Spring Creek below fish hatchery). Yellow-green algae were found in 5 samples and were most abundant in Blaine Spring Creek. The red alga Audouinella was found only at the lower Elk River site and the brown alga Heribaudiella was found only at the lower Gazelle Creek site. The number of genera of non-diatom algae ranged from 2 near the mouth of Blaine Spring Creek to 9 at the lower site on Elk River.

Nitrogen-fixing Algae. Cyanobacteria that possess a certain type of specialized cell (heterocyst) are capable of fixing molecular or atmospheric nitrogen under aerobic conditions. These algae have a competitive advantage in waters where nitrogen is in short supply relative to phosphorus and other nutrients. Among tributaries of the Madison River, algae with heterocysts include Calothrix, Nostoc, and Tolypothrix. These algae were present in Antelope Creek, Elk River, upper Gazelle Creek, Buford Creek, and Blaine Spring Creek at bypass. Nitrogen may be the limiting nutrient at these sites.

Mat-forming Filamentous Algae. Large standing crops of filamentous algae can interfere with swimming, boating, fishing, and other water uses. Algal genera in tributaries of the Madison River that are known to produce nuisance growths in North American waters are Cladophora, Oedogonium, Oscillatoria, Rhizoclonium, Spirogyra, and Ulothrix (Wehr and Sheath 2003). One or more of these genera were dominant or abundant only at the lower site on Elk River, where Cladophora was abundant. Among sites in this sample set, this site is most likely to support nuisance growths of filamentous algae. 
Pollution-tolerant Algae. Palmer (1969) listed 60 algal genera that are most tolerant of organic pollution. Genera of non-diatom algae in this sample set that are on Palmer's list are Oscillatoria (\#2), Closterium (\#16), Spirogyra (\#21), Ulothrix (\#30), Cladophora (\#42),

Cosmarium (\#53), and Tribonema (\#55). Sites where one or more of these genera were frequent, abundant, or dominant are: ANTLC01, ELKR02, GAZLC01, GAZLC02, and all sites on Blaine Spring Creek. These sites are the ones that most likely receive the heaviest loads of organic pollution. Genera on Palmer's list were common at the other two sites.

Other Indicator Algae. When abundant, certain genera of algae can provide useful clues about environmental conditions. The two genera of chrysophytes that were present in these samples are good indicator algae. Tribonema, which is sensitive to organic pollution and prefers cool waters, was a dominant in Blaine Spring Creek below the fish hatchery. Vaucheria, the other chrysophyte, requires steady flows of cool water. Vaucheria was common in Gazelle Creek (both sites) and frequent to abundant at the upper two sites on Blaine Spring Creek.

The filamentous green alga Mougeotia has often been reported to increase in abundance in lakes that are subject to atmospheric deposition and undergoing acidification. Among study sites in the Madison River TMDL planning area, Mongeotia was found only in Elk River (both sites), where it was common to frequent.

The foliose, seaweed-like green alga Prasiola has been reported as abundant at sites that are enriched with forms of organic nitrogen, such as bird droppings, as well as in cold mountain streams (Wehr and Sheath 2003). Prasiola was found only at the lower site on Gazelle Creek, where it was abundant.

\section{Diatoms (Table 5)}

Diatoms were present in all of the samples and ranked first in biomass at all sites except the upper site on Blaine Spring Creek, where they ranked fourth. All of the 22 major diatom 
species in tributaries of the Madison River are either sensitive to organic pollution or only somewhat tolerant of organic pollution. None of the major diatom species is most tolerant of organic pollution (Table 5).

In general, diatom species richness, diversity, and equitability were excellent. Most sites supported more than 50 species and diversity values in excess of 4.00 . Only one site (Blaine Spring Creek at bypass) had diversity values that indicated unusual stress, and this stress was probably natural in origin. At none of the sites did the dominant species contribute more than half of the cells to the diatom assemblage (Table 5).

High diatom diversity in these streams infers the absence of natural stressors, such as steep gradients, fast currents, low light, low nutrients, and constant cold temperatures. The predominance of non-motile, free-living taxa (Diatoma spp., Fragilaria vaucheriae, Melosira varians, Staurosira construens, Staurosirella leptostauron, Synedra ulna) relative to attached species (Achnanthidium spp., Cocconeis placentula, Rhoicosphenia abbreviata) implies that most sites have gentle gradients and slow current velocities compared to other mountain streams. This is confirmed by the relatively low disturbance index at most sites (Table 5).

Besides the absence of natural stressors, high diatom diversity in these streams also suggests moderate nutrient enrichment (little competition for available nutrients) and complex microhabitats that are similar to prairie streams. Pollution index values, which indicate the amount of organic loading, are lower than in most mountain streams. Many are near or below the threshold for minor impairment (2.50). Similarly, siltation index values tend to be higher in Madison River tributaries than in most mountain streams, with the notable exception of the upper site on Blaine Spring Creek (Table 5).

All but one of the sites supported teratological (deformed or physically abnormal) diatom cells. In large numbers, abnormal cells may indicate metals toxicity. However, the percentage of abnormal cells was within acceptable limits at all sites. The lower site on Gazelle Creek supported the largest percentage of abnormal cells (Table 5). 
Similarity index values indicate that ecological changes between adjacent sites on the same stream varied from un-measurable $(>60 \%)$ to minor $(40-60 \%)$ to moderate $(20-40 \%)$. The similarity index ("percent community similarity") measures the cumulative percentage of cells of each taxon that are shared by two stream sites. The two sites on Elk River had virtually identical diatom assemblages. On the other hand, there was a very large change in the diatom assemblage between the upper site on Blaine Spring Creek and the site below the fish hatchery.

The diatom order Rhopalodiales includes genera (Epithemia and Rhopalodia) that are known to harbor nitrogen-fixing endosymbionts within their cells. These symbiotic nitrogenfixers are single-celled cyanobacteria (blue-green algae). Nitrogen is likely the limiting nutrient in waters that support large numbers of diatoms in the order Rhopalodiales. All of the sites in this sample set supported less than $0.36 \%$ Rhopalodiales, which represents 3 or fewer valves in a count of 800 valves. On this basis, there was no clear evidence of nitrogen limiting conditions at any of the sites.

The following paragraphs highlight the key findings for each stream and each site based upon the major diatom species and core diatom metrics in Table 5.

Antelope Creek. This site supported a large number of diatoms that are somewhat tolerant of organic pollution. The pollution index here suggests minor impairment from organic loading. An elevated number of motile diatoms also indicates minor sedimentation. Aside from a few abnormal diatom cells, this site had excellent biological integrity and provided full support of aquatic life uses.

Elk River. Diatom metrics at the lower site suggest moderate impairment from sedimentation and partial support of aquatic life uses. This was the only site in the sample set to provide less than full support of aquatic life uses. The pollution index at this site was borderline on minor impairment. At the upper site there was minor impairment from sedimentation but otherwise excellent biological integrity. The two sites were virtually identical, floristically. 
Gazelle Creek. Aside from a few abnormal cells, the upper site on Gazelle Creek had excellent biological integrity. At the lower site, an elevated number of abnormal cells, an elevated percentage of motile diatoms, and slightly depressed species richness and diversity suggest minor impaiment from sedimentation and possible chronic metals toxicity. Otherwise, this site had excellent biological integrity. The two sites shared slightly more than half of their diatom assemblages, indicating only minor changes in environmental conditions between them.

Buford Creek. Buford Creek supported a large number of motile diatoms that approached the threshold for moderate impairment and partial support of aquatic life uses. The pollution index value at this site approached the threshold for minor impairment. Other metrics indicate good to excellent biological integrity.

Blaine Spring Creek. The upper site on Blaine Spring Creek (at bypass) supported a distinctive diatom flora dominated by Achnanthidium minutissimum. Other major species hereDiatoma mesodon and Staurosirella leptostauron-indicate cold gently flowing waters typical of spring creeks. The fourth major taxon at this site, Planothidium lanceolatum, is adapted to living attached to sand grains and suggests a sandy substrate. The low species richness and diversity values here are probably due to consistently cold water temperatures.

A major change in the diatom assemblage and environmental conditions occurred between the upper site and the site below the fish hatchery. The latter site had a depressed pollution index indicating elevated loading of organic compounds and minor impairment. Otherwise, this site had good biological integrity and provided full support of aquatic life uses.

The pollution index rebounded at the lower two sites on Blaine Spring Creek, indicating reduced loading of organic compounds. However, these sites supported elevated numbers of motile diatoms that resulted in siltation index values in the minor impairment range. These two sites were similar, floristically, and shared about half of their diatom assemblages. 


\section{Modal Categories (Table 6)}

Several ecological attributes assigned by Stevenson and Van Dam et al. (1994) were selected from the diatom reports in the appendix. Modal categories of these attributes were extracted to characterize water quality tendencies in tributaries of the Madison River (Table 6).

The majority of diatoms at most sites in the sample set are non-motile, alkaliphilous, nitrogen autotrophs that prefer fresh waters, moderate BOD levels, high oxygen levels, and elevated concentrations of inorganic nutrients. However, the modal categories at some sites represent significant departures in water quality when compared to most other sites in the sample set. These departures, which may reflect increases or decreases in water quality, are discussed below.

Diatom species that prefer circumneutral (as opposed to alkaline) $\mathrm{pH}$ values were most abundant at the upper site on Blaine Spring Creek. This site is likely to have lower $\mathrm{pH}$ values than the remaining sites.

The modal category for oxygen demand was less than "continuously high" at six sites. Most diatoms were in the "fairly high" category in Buford Creek and Blaine Spring Creek near mouth. Moderate oxygen demand was the modal category at the upper site on Elk River, the lower site on Gazelle Creek, and the two middle sites on Blaine Spring Creek.

Beta-mesosaprobous was the level of saprobity at all but one site. This represents a dissolved oxygen saturation of $70-85 \%$ and $2-4 \mathrm{mg} / \mathrm{L}$ of biochemical oxygen demand $\left(\mathrm{BOD}_{5}\right)$. The level of saprobity was higher (alpha-mesosaprobous) in Blaine Spring Creek below the fish hatchery. The alpha-mesosaprobous level corresponds to $25-70 \%$ saturation of dissolved oxygen and $4-13 \mathrm{mg} / \mathrm{L} \mathrm{BOD}_{5}$.

At two sites-Antelope Creek and Blaine Spring Creek at bypass-the majority of diatoms represented species that tolerate a wide range of inorganic nutrient concentrations, from oligotrphentic to eutraphentic. Diatoms indicate eutrophic conditions at the other sites. 


\section{References}

APHA. 1998. Standard Methods for the Examination of Water and Wastewater. 20 ${ }^{\text {th }}$ Edition. American Public Health Association, Washington, D.C.

Bahls, L.L. 1979. Benthic diatom diversity as a measure of water quality. Proceedings of the Montana Academy of Sciences 38:1-6.

Bahls, L.L. 1993. Periphyton Bioassessment Methods for Montana Streams (revised). Montana Department of Health and Environmental Sciences, Helena.

Bahls, L.L., Bob Bukantis, and Steve Tralles. 1992. Benchmark Biology of Montana Reference Streams. Montana Department of Health and Environmental Sciences, Helena.

Barbour, M.T., J. Gerritsen, B.D. Snyder, and J.B. Stribling. 1999. Rapid Bioassessment Protocols for Use In Streams and Wadeable Rivers: Periphyton, Benthic Macroinvertebrates and Fish. Second Edition. EPA/841-B-99-002. U.S. Environmental Protection Agency, Office of Water, Washington, D.C.

Beaver, Janet. 1981. Apparent Ecological Characteristics of Some Common Freshwater Diatoms. Ontario Ministry of The Environment, Technical Support Section, Don Mills, Ontario.

Hieber, Maggi, C.T. Robinson, S. R. Rushforth, and Urs Uehlinger. 2001. Algal communities associated with different alpine stream types. Arctic, Antarctic, and Alpine Research 33(4):447-456.

Johansen, J.R. 1999. Diatoms of Aerial Habitats. Chapter 12 in Stoermer, E.F., and J.P. Smol (eds.), The Diatoms: Applications For the Environmental and Earth Sciences, Cambridge University Press, New York.

John, D.M., B.A. Whitton, and A.J. Brook (eds.). 2002. The Freshwater Algal Flora of the British Isles: An Identification Guide to Freshwater and Terrestrial Algae. Cambridge University

Karr, J.R., and D.R. Dudley. 1981. Ecological perspectives on water quality goals. Environmental Management 5:55-69.

Kawecka, B. 1990. The effect of flood-control regulation of a montane stream on the communities of sessile algae. Acta Hydrobiology 32:345-354.

Krammer, Kurt. 1997a. Die cymbelloiden Diatomeen: Eine Monographie der weltweit bekannten Taxa. Teil 1. Allgemeines and Encyonema Part. J. Cramer, Berlin.

Krammer, Kurt. 1997b. Die cymbelloiden Diatomeen: Eine Monographie der weltweit bekannten Taxa. Teil 2. Encyonema part., Encyonopsis and Cymbellopsis. J. Cramer, Berlin.

Krammer, Kurt. 2002. Cymbella. Volume 3 in Diatoms of Europe, Horst Lange-Bertalot, ed. A.R.G. Gantner Verlag K.G., Germany.

Krammer, K., and H. Lange-Bertalot. 1986. Bacillariophyceae, Part 2, Volume 1: Naviculaceae. In Ettl, H., J Gerloff, H. Heynig, and D. Mollenhauer (eds.), Freshwater Flora of Middle Europe. Gustav Fischer Publisher, New York.

Krammer, K., and H. Lange-Bertalot. 1988. Bacillariophyceae, Part 2, Volume 2: Bacillariaceae, Epithemiaceae, Surirellaceae. In Ettl, H., J. Gerloff, H. Heynig, and D. Mollenhauer (eds.), Freshwater Flora of Middle Europe. Gustav Fischer Publisher, New York. 
Krammer, K., and H. Lange-Bertalot. 1991 a. Bacillariophyceae, Part 2, Volume 3: Centrales, Fragilariaceae, Eunotiaceae. In Ertl, H., J. Gerloft, H. Heynig, and D. Mollenhauer (eds.), Freshwater Flora of Middle Europe. Gustav Fischer Publisher, Stuttgart.

Krammer, K., and H. Lange-Bertalot. 1991b. Bacillariophyceae, Part 2, Volume 4: Achnanthaceae, Critical Supplement to Navicula (Lineolatae) and Gomphonema, Complete List of Literature for Volumes 1-4. In Ettl, H., G. Gartner, J. Gerloff, H. Heynig, and D. Mollenhauer (eds.), Freshwater Flora of Middle Europe. Gustav Fischer Publisher, Stuttgart.

Lange-Bertalot, Horst. 1979. Pollution tolerance of diatoms as a criterion for water quality estimation. Nova Hedwigia 64:285-304.

Lange-Bertalot, Horst. 1993. 85 new taxa and much more than 100 taxonomic clarifications supplementary to Susswasserflora von Mitteleuropa Vol. 2/1-4. J. Cramer, Berlin.

Lange-Bertalot, Horst. 1996. Rote Liste der limnischen Kieselalgen (Bacillariophyceae) Deutschlands. Schr.-R. f. Vegetationskde., H. 28, pp. 633-677. BfN, Bonn-Bad Godesberg.

Lange-Bertalot, Horst. 2001. Navicula sensu stricto: 10 Genera Separated from Navicula sensulato; Frustulia. Volume 2 in Diatoms of Europe, Horst Lange-Bertalot, ed. A.R.G. Gantner Verlag K.G., Germany.

Lowe, R.L. 1974. Environmental Requirements and Pollution Tolerance of Freshwater Diatoms. EPA-670/4-74-005. U.S. Environmental Protection Agency, National Environmental Research Center, Office of Research and Development, Cincinnati, Ohio.

McFarland, B.H., B.H. Hill, and W.T. Willingham. 1997. Abnormal Fragilaria spp. (Bacillariophyceae) In streams impacted by mine drainage. Journal of Freshwater Ecology 12(1):141-149.

Morales, E.A., and Marina Potapova. 2000. Third NAWQA Workshop on Harmonization of Algal Taxonomy, May 2000. Patrick Center for Environmental Research, The Academy of Natural Sciences, Philadelphia.

Nicholls, K.H., and D.E.Wujek. 2003. Chrysophycean Algae. Chapter 12 (pp. 471-509) in Wehr, J.D., and R.G. Sheath (eds.), Fresliwater Algae of North America: Ecology and Classification. Academic Press, New York:

Palmer, C.M. 1969. A composite rating of algae tolerating organic pollution. Joumal of Phycology 5:78-82.

Palmer, C.M. 1977. Algae and Water Pollution: An Illustrated Manual on the Identification, Significance, and Control of Algae in Water Supplies and in Polluted Water. EPA-600/9-77-036.

Plafkin, J.L., M.T. Barbour, K.D. Porter, S.K. Gross, and R.M. Hughes. 1989. Rapid Bioassessment Protoçols for Use in Rivers and Streams: Benthic Macroinvertebrates and Fish. EPA 440-4-89-001.

Prescott, G.W. 1962. Algae of the Western Great Lakes Area. Wm. C. Brown Company, Dubuque, Iowa.

Prescott, G.W. 1978. How to Know the Freshwater Algae. Third Edition. Wm. C. Brown Company Publishers, Dubuque, Iowa.

Reichardt, Erwin. 1997. Taxonomische Revision des Artenkomplexes um Gomphonema pumilum (Bacillariophyta). Nova Hedwigia 65( l-4):99-129.

Reichardt, Erwin. 1999. Zur Revision der Gattung Gomphonema. A.R.G. Gantner Verlag, Distributed by Koeltz Scientific Books, Konigstein, Germany. 
Renfro, H.B., and D.E. Feray. 1972. Geological Highway Map of the Northern Rocky Mountain Region. American Association of Petroleum Geologists, Tulsa, Oklahoma.

Smith, G.M. 1950. The Fresh-Water Algae of The United States. McGraw-Hill Book Company, New York

Stevenson, R.J., and Y. Pan. 1999. Assessing Environmental Conditions in Rivers and Streams with Diatoms. Chapter 2 in Stoermer, E.F., and J.P. Smol (eds.), The Diatoms: Applications For the Environmental and Earth Sciences, Cambridge University Press, New York.

Stewart, W.D.P., P. Rowell, and A.N. Rai. 1980. Symbiotic Nitrogen-Fixing Cyanobacteria. Pp. 239-277 in Stewart, W.D.P., and J. Gallo (eds.), Nitrogen Fixation, Academic Press, New York.

USDA. 1976. Climax Vegetation of Montana (map). U.S. Department of Agriculture, Soil Conservation Service, Cartographic Unit, Portland.

USEPA. 2000. Level III Ecoregions of the Continental United States (map). National Health and Environmental Effects Research Laboratory, U.S. Environmental Protection Agency, Corvallis, Oregon.

Van Dam, Herman, Adrienne Mertens, and Jos Sinkeldam. 1994. A coded checklist and ecological Indicator values of freshwater diatoms from The Netherlands. Netherlands Journal of Aquatic Ecology 28(1):117-133.

Weber, C.I. (ed.). 1973. Biological Field and Laboratory Methods for Measuring the Quality of Surface Waters and Effluents. EPA-670/4-73-001. U.S. Environmental Protection Agency, National Environmental Research Center, Office of Research and Development, Cincinnati, Ohio.

Wehr, J.D., and R.G. Sheath. 2003. Freshwater Algae of North America: Ecology and Classification. Academic Press, New York.

Whittaker, R.H. 1952. A study of summer foliage insect communities in the Great Smoky Mountains. Ecological Monographs 22:1-44.

Woods, A.J., Omernik, J.M., Nesser, J.A., Shelden, J., and S.H. Azevedo. 1999. Ecoregions of Montana (color poster with map), U.S. Geological Survey, Reston, Virginia. 


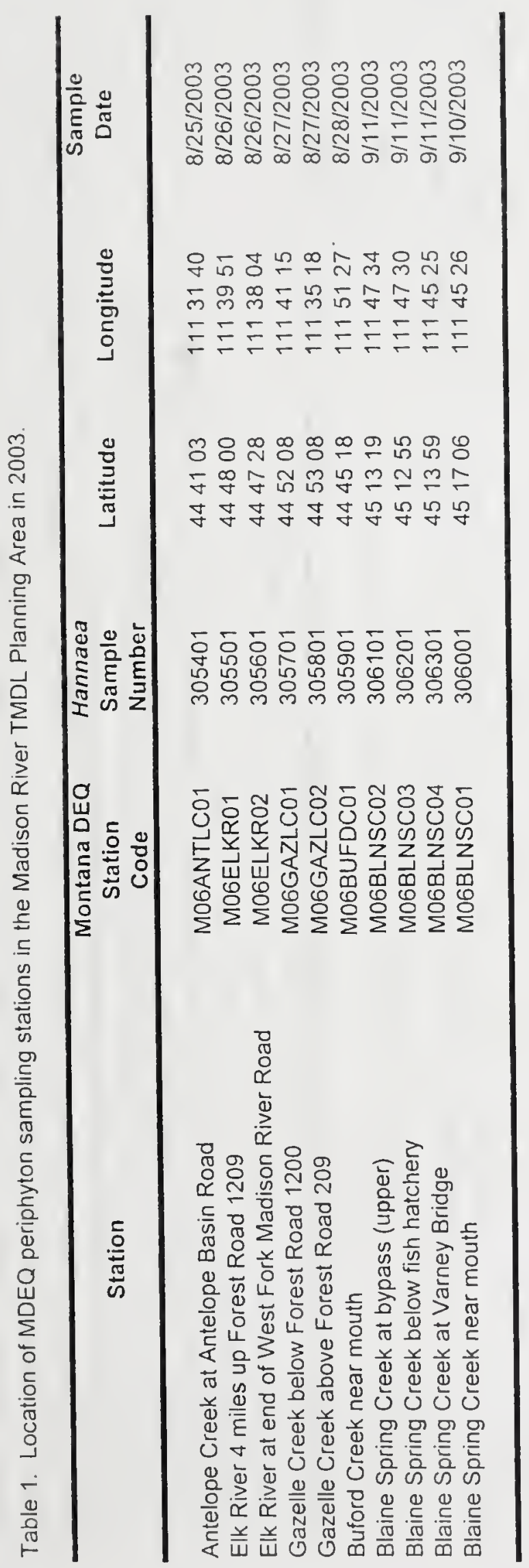




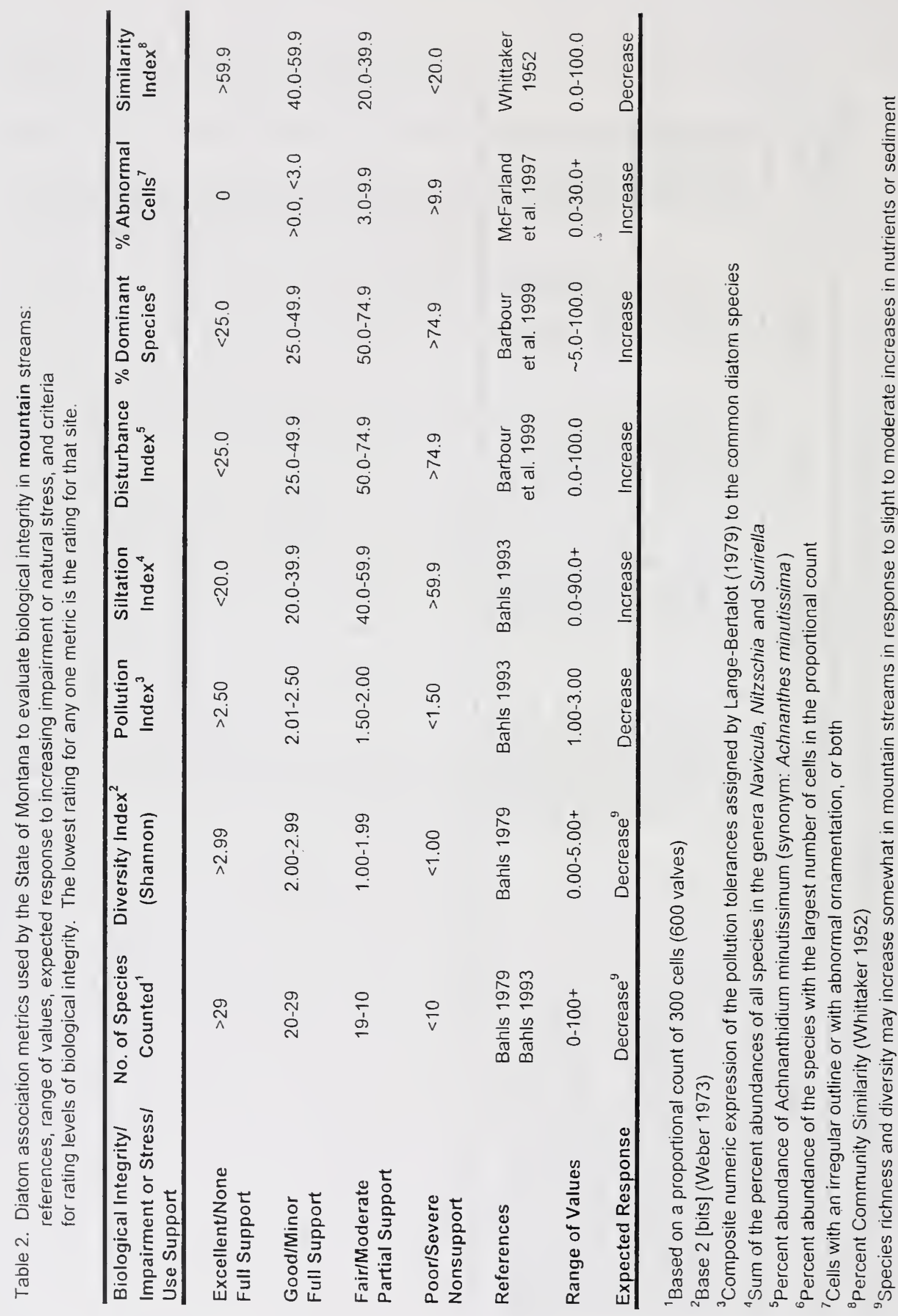




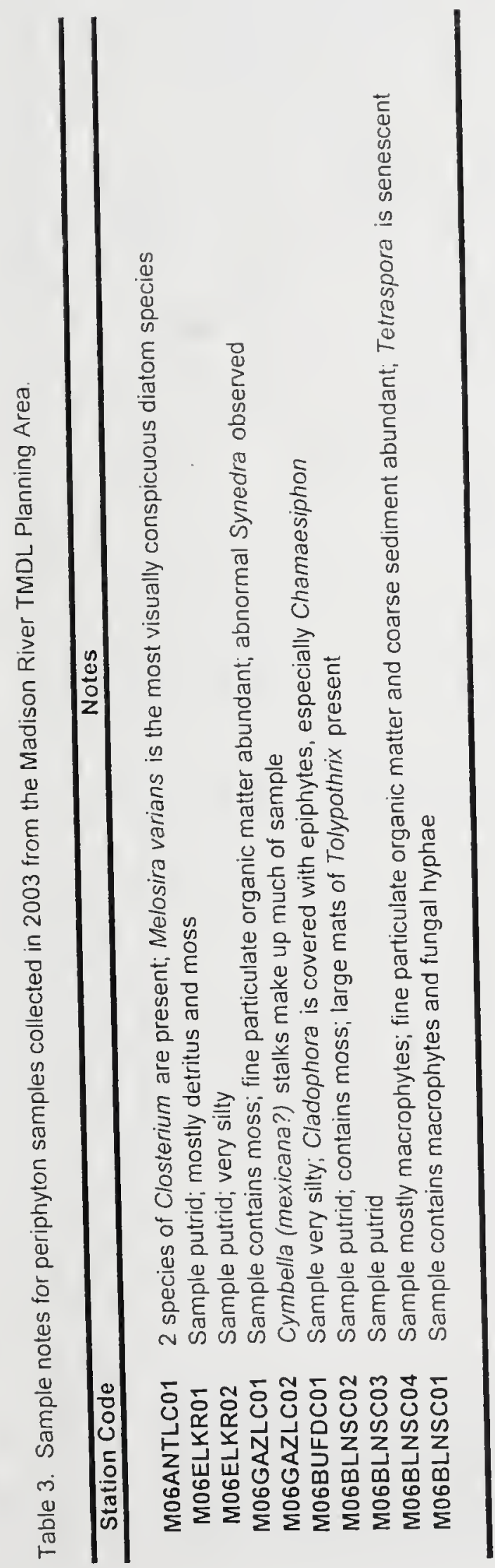




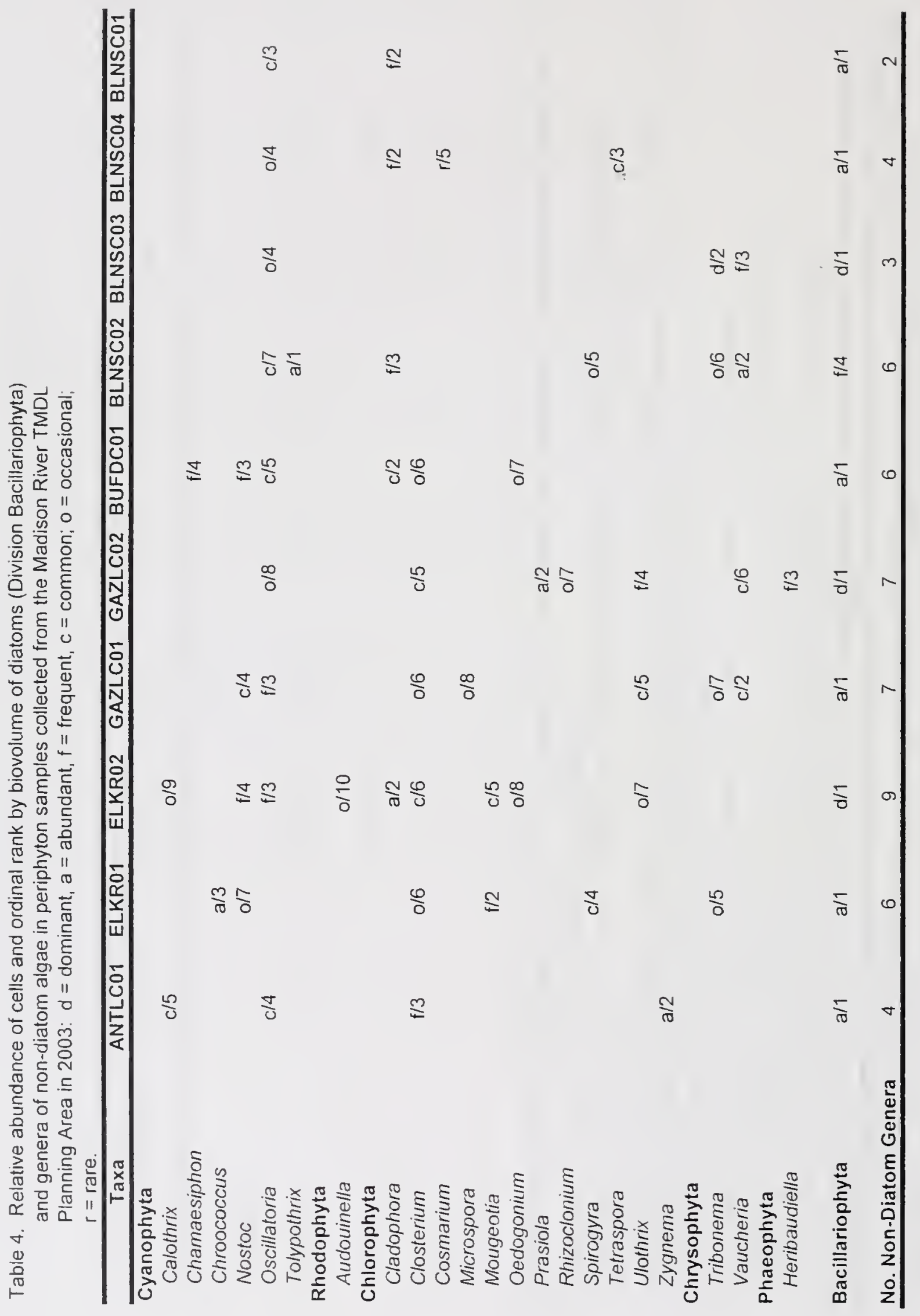




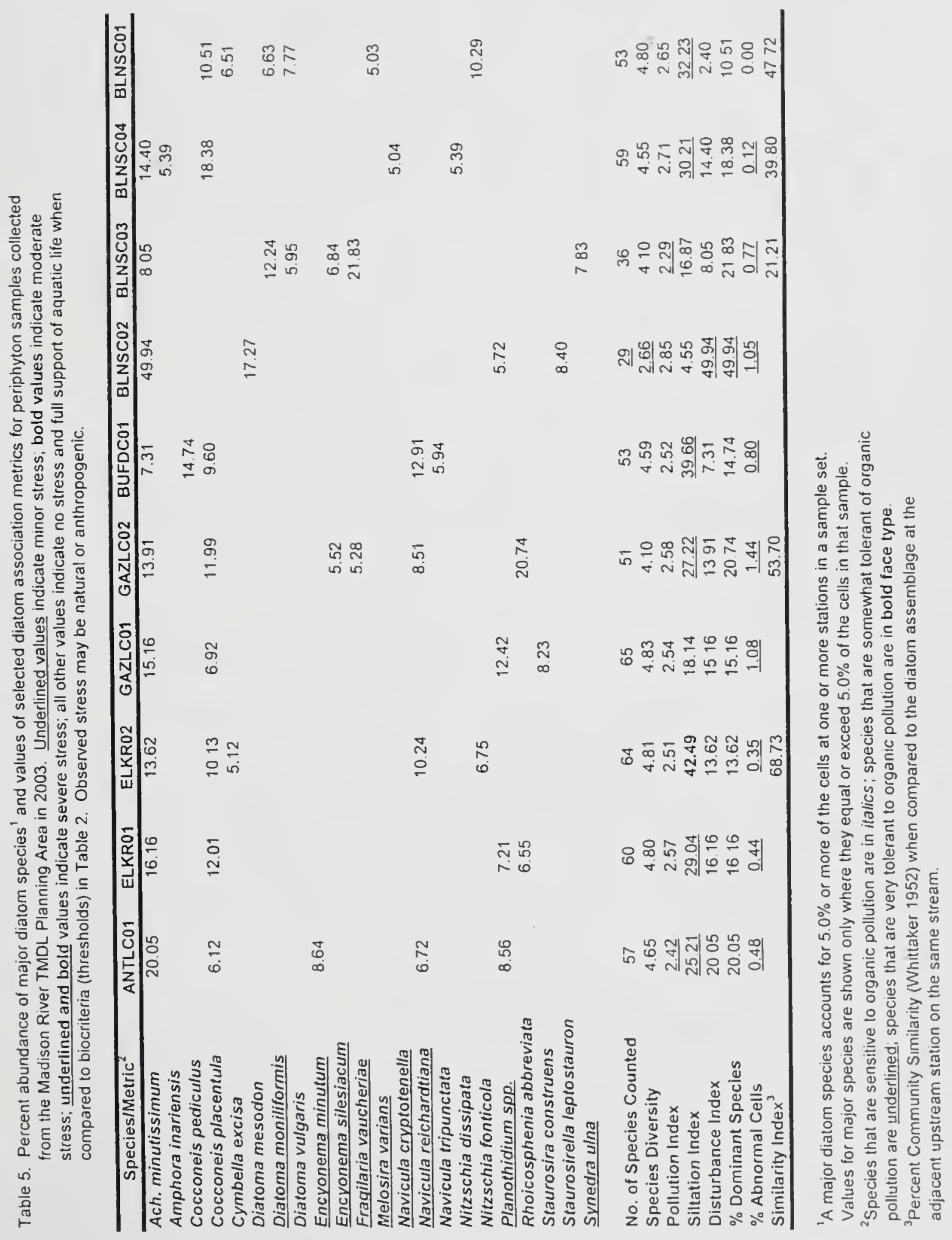




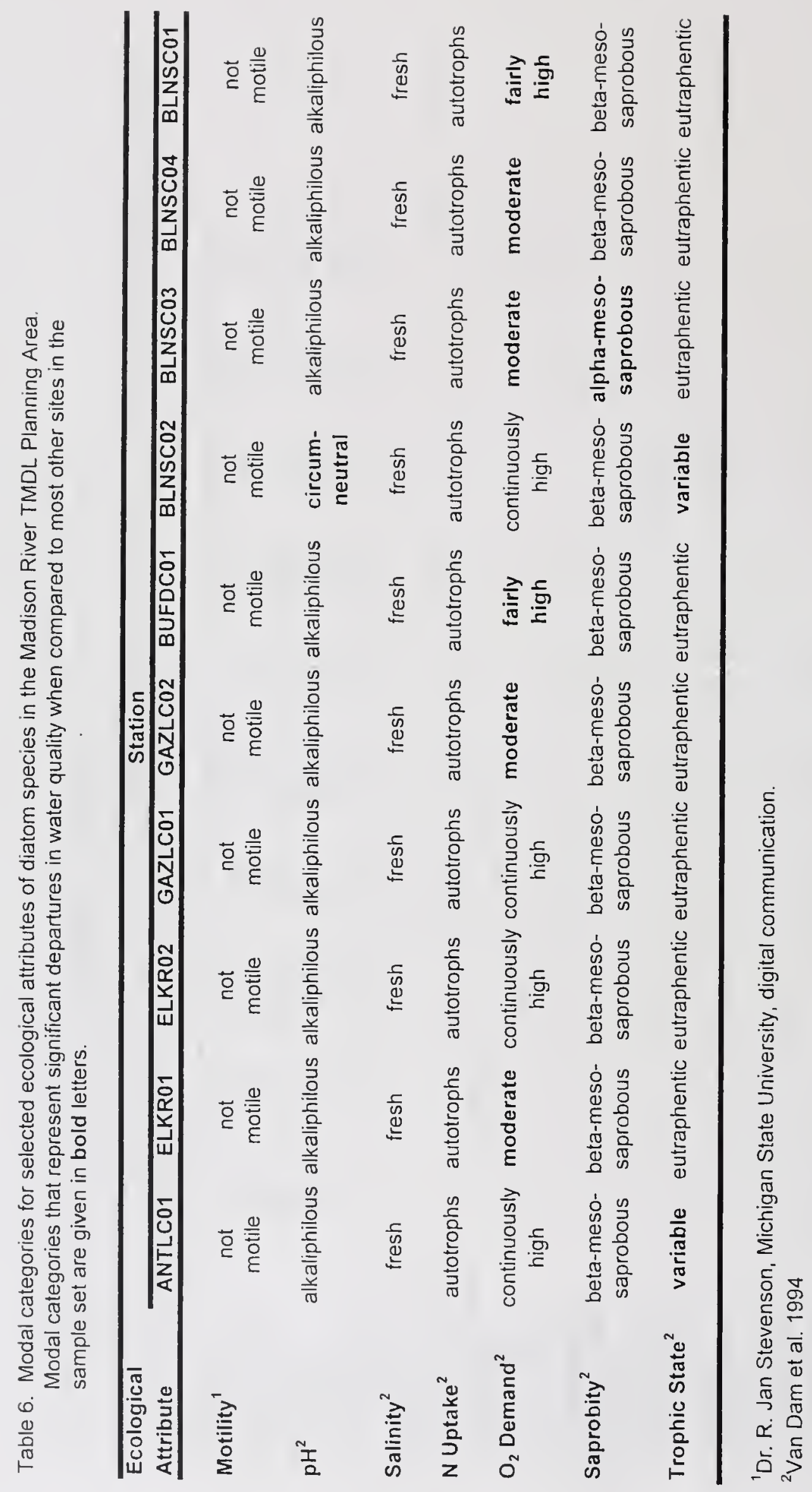

